\section{Ringing in the New Year!}

A new calendar year has come-but what a year just finished! Reflecting on the programs, products, and services of the Institute, it is clear that we are riding high into the New Year with great momentum.

Our members, Executive, and Board were all buzzing after the successful Annual General Meeting and Conference in Salt Lake City held jointly with the Society of American Foresters (SAF) and in partnership with IUFRO (International Union of Forest Research Organizations). This energy has not waned, invigorating our membership and enabling additional conversations with the SAF. In December, face-to-face meetings took place in Toronto between the CIF/IFC Executive and SAF Executive members to consider partnership opportunities. The parallels between the two organizations-including the challenges we both face and the common direction we are looking to takeconfirmed the need collaborate. Moreover, the willingness to partner as well as the genuine enthusiasm expressed by both parties bode well for future collaboration. It is safe to say that we will not have to wait another 10 years for CIF/IFC-SAF collaboration. Moving into the New Year, developing crossborder partnerships with SAF State Societies and the Institute's Sections through shared working groups, workshops, and knowledge exchange products will be a priority.

The Institute's partnership with the Prince of Wales' Duchy of Cornwall is another initiative that continues to flourish. Late in 2014 we announced the inaugural Prince of Wales Forest Leadership Award. In collaboration with the UK's Institute of Chartered Foresters, TD Bank Group, and the Duchy of Cornwall, the Institute is delivering an international student exchange program to give future leaders in Canada and the UK the opportunity of a lifetime. Award winners (two each from Canada and the UK) will be given a $\$ 12-000$ bursary to spend their sum- mer abroad gaining forestry work experience, building their networks, and fostering personal growth and professional development. The inaugural year has already been successful. Applicants from coast to coast have made the Prince of Wales Forest Leadership Award one of the most competitive awards in the Institute's history. While only two recipients will be named in mid-February, the future of the forest sector looks bright with so many young people possessing the passion to be future leaders.

At the national level, our knowledge exchange program under the CIF-SEEK platform continues to be a staple of the Institute's value. Through workshops, seminars, and other products and services, CIF-SEEK and our forest science partners have effectively provided the latest science to help forest practitioners and professionals stay competent and current. The Institute wrapped up 2014 with a popular CIF-SEEK program in collaboration with the Invasive Species Centre. Three international knowledgesharing workshops examined today's most problematic invasive species, including those in forested and urban landscapes and wetland environments. From phragmites to mountain pine beetle to Asian carp-an array of invasive species was examined along with the threats they pose and current management options. The workshops were held in conjunction with a national electronic lecture series where the topics were further explored. This series attracted over 600 participants each week, demonstrating the concern over invasive species and the need for understanding and management strategies across Canada.

Success was evident in our partnership with the Canadian Wood Fibre Centre (CWFC). Several workshops highlighted forest bioenergy and enhanced forest productivity, enabling knowledge exchange among forest practitioners and professionals. Another noteworthy accomplishment

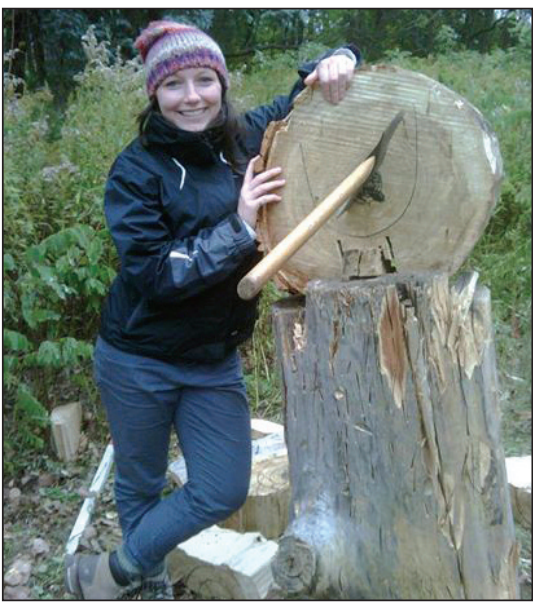

Dana Collins

Acting Executive Director/ Directrice générale intérimaire

within this partnership included the recent publication, Success Stories from Canadian Forests, a compilation of concise, plain-language stories based on the premise of peer-to-peer communication. By distributing the publication to our membership, partners, and other affiliated organizations, we are showcasing Canadian forestry, forest science, and innovation at its very best.

As we move further into the New Year, the Institute will continue to deliver a national program with the CWFC. An eight-week long national electronic series is scheduled for February and March to explore the realities and possibilities of forest biomass in Canada. A series of targeted workshops and technical sessions will also take place from coast to coast, encouraging the implementation of best management practices and enhanced forest inventory tools.

With the CIF/IFC staff well-rested after a much-needed holiday break, we will be looking forward to continuing to work with our partners to provide maximum value to members. 


\section{Fêtons l'arrivée de la nouvelle année !}

U ne nouvelle année commence - mais quelle année nous avons connue en 2014! En repensant aux programmes, aux produits et aux services offerts par l'Institut, il est évident que nous avons de quoi célébrer l'arrivée de la nouvelle année avec enthousiasme.

Nos membres, le bureau de direction et le conseil d'administration débordaient d'enthousiasme à la suite du succès entourant l'assemblée générale et le congrès annuel tenus à Salt Lake City de concert avec la Society of American Foresters et en partenariat avec l'IUFRO (Union internationale des instituts de recherches forestières). L'énergie dégagée à cette occasion ne s'est pas dissipée et continue à stimuler les adhésions en plus de promouvoir les discussions avec la SAF. Ce fut le cas en décembre alors que les membres du bureau de direction de l'Institut et leurs homologues de la SAF se sont réunis à Toronto afin détudier les possibilités de partenariats. Les nombreux points que les deux organisations ont en commun ainsi que les défis auxquels elles font face et lorientation qu'elles veulent adopter ont confirmé quelles ont tout intérêt à collaborer. La volonté d'établir un partenariat ainsi que l'enthousiasme réel manifesté par les deux parties augure bien pour l'avenir de cette collaboration. Il ne devrait certainement pas sécouler encore dix ans avant que sétablisse une collaboration entre l'Institut et la SAF. Au cours de la prochaine année, nous avons établi comme priorités lélaboration de partenariats transfrontaliers avec les chapitres locaux de la SAF et les sections de l'Institut par l'entremise des groupes de travail, d'ateliers et de produits d'échange de connaissances.

Le partenariat de l'Institut mis en place avec le duché de Cornwall du Prince de Galles est un autre exemple d'un projet qui continue de progresser. À la fin de 2014, nous avons dévoilé le prix de leadership forestier du Prince de Galles. En collaboration avec l'Institute of Chartered Foresters du Royaume-Uni, du Groupe financier de la Banque TD et le duché de Cornwall, l'Institut a mis en place un programme d'échange d'étudiants visant à offrir aux futurs chefs de file du Canada et du R.-U. une occasion unique d'acquérir de l'expérience. Les récipiendaires du prix (deux en provenance du Canada et deux du R.-U.) recevront une bourse de 12000 \$ qui leur permettra de passer un été à l'étranger pour y travailler, établir des réseaux de contacts et poursuivre leur développement personnel et professionnel. La première année de ce programme aura connu un succès retentissant. Des candidatures venant de partout au pays ont fait du prix de leadership forestier $d u$ Prince de Galles l'un des plus convoités de toute l'histoire de l'Institut. Même si les noms des deux gagnants ne seront connus quà la mi-février, l'avenir du secteur forestier semble prometteur à la vue de tous ces jeunes brûlant de devenir les leaders de demain.

Sur la scène nationale, notre programme d'échange de connaissance opérant à partir de la plateforme CIFSEEK continue dêtre un fleuron de l'Institut. À l'aide d'ateliers, de conférences et d'autres produits et services, le CIF-SEEK et nos partenaires en sciences forestières ont diffusé les plus récentes avancées scientifiques, aidant ainsi les professionnels du secteur forestier à demeurer compétents et informés. L'Institut a terminé l'année 2014 avec un programme fort populaire du CIFSEEK, qu'il a livré en collaboration avec le Centre sur les espèces envahissantes. Il a ainsi tenu trois ateliers internationaux afin de favoriser l'échange de connaissances sur les principales espèces envahissantes de l'heure, notamment celles des paysages forestiers et urbains et celles des milieux humides. On a ainsi passé en revue un ensemble d'espèces envahissantes - des phragmites au dendroctone du pin en passant par la carpe asiatique - ainsi que les menaces qu'elles représentent et les options disponibles pour les gérer. Ces ateliers étaient accompagnés d'une série de conférences électroniques nationale qui a permis d'explorer le sujet

\begin{tabular}{|c|c|c|c|c|c|}
\hline \multicolumn{6}{|c|}{ CIF/IFC Executive Committee/Bureau de direction } \\
\hline \multicolumn{6}{|c|}{$\begin{array}{l}\text { President/Président - Al Stinson } \\
\text { Chief Executive Officer/Président directeur général - vacant }\end{array}$} \\
\hline \multicolumn{3}{|c|}{$\begin{array}{l}1^{\text {st }} \text { Vice-President/1er vice-président - Jonathan Lok, R.F.T. } \\
2^{\text {nd }} \text { Vice-President/2e vice-président - Megan Smith }\end{array}$} & \multicolumn{3}{|c|}{$\begin{array}{l}\text { Past President/Président sortant - C.T. (Tat) Smith } \\
\text { Executive Director/Directeur général - Dana Collins (acting) }\end{array}$} \\
\hline Section & $\begin{array}{l}\text { Director/ } \\
\text { directeur }\end{array}$ & $\begin{array}{l}\text { Section Chair/ } \\
\text { président de section }\end{array}$ & Section & $\begin{array}{l}\text { Director/ } \\
\text { directeur }\end{array}$ & $\begin{array}{l}\text { Section Chair/ } \\
\text { président de section }\end{array}$ \\
\hline Algonquin & Scott McPherson & Lacey Rose & Nova Scotia & Robert Young & Robert Young \\
\hline Cariboo & Ed Morrice & Rebecca Bowler & Orléans & Vincent Chamberland & Sylvie Carles \\
\hline Central Ontario & Tom Noland & Lesley Phillips & Ottawa Valley & Mike Rosen & Ken Farr \\
\hline Klondike & - & - & Rocky Mountain & Lorne West & Alex Drummond \\
\hline Lake of the Woods & Jack Harrison & Tara Pettit & Saskatchewan & Dwayne Dye & Vicki Gauthier \\
\hline Manitoba & Brad Epp & Kristen Adair & Southern Ontario & Albert Hovingh & Christine Leduc \\
\hline Maritime & Anne LeBrun Ruff & Anne LeBrun Ruff & Thompson/ & Mike Waithe & Clare Kooistra \\
\hline Newfoundland & Colin Carroll & Allan Masters & Okanagan & & \\
\hline and Labrador & & & Vancouver & Janet Mitchell & Candace Parsons \\
\hline Northern Ontario & Al Thorne & Nikki Wood & Vancouver Island & Richard Dominy & Jocelin Teron \\
\hline $\begin{array}{l}\text { Northwestern } \\
\text { Ontario }\end{array}$ & Doug Reid & Karen Saunders & & & \\
\hline
\end{tabular}


davantage. La série de conférences a attiré plus de 600 participants chaque semaine, démontrant ainsi l'intérêt porté envers les espèces envahissantes et la nécessité de mieux les connaître et d'établir des stratégies de contrôle partout au Canada.

Notre partenariat avec le Centre canadien sur la fibre de bois (CCFB) a aussi connu un succès marquant. Plusieurs ateliers se sont penchés sur la biotechnologie forestière et l'accroissement de la productivité des forêts, permettant aux professionnels de la foresterie de partager leurs connaissances. Ce partenariat aura donné lieu à une autre réalisation importante avec la publication récemment de "Success Stories from Canadian Forests (Histoire de réussites dans les forêts canadiennes) », une compilation de courts récits en langage courant basés sur des communications entre collègues. En distribuant cette publication à nos membres, à nos partenaires et à d'autres organisations affiliées, nous serons en mesure de mettre en valeur la foresterie canadienne, les sciences forestières et les innovations du milieu à leur meilleur.

Plus tard cette année, l'Institut poursuivra la réalisation de son programme national avec le CCFB. Il offrira en outre une série de conférences électroniques de huit semaines, en février et mars, sous le thème des réalités et des possibilités liées à la biomasse forestière au Canada. On envisage aussi d’offrir une série d'ateliers spécialisés et de séances techniques d'un bout à l'autre $\mathrm{du}$ pays afin de promouvoir les meilleures pratiques d'aménagement et l'utilisation d'outils modernes d'inventaire forestier.

Après un repos bien mérité durant la période des Fêtes, le personnel de l'Institut sera de retour en janvier pour continuer d'offrir aux membres le meilleur de lui-même!

\section{Hot News from the Institute/En direct des bureaux de l'Institut}

\section{CIF/IFC 2014 Annual Confer- ence and Business Meetings}

The Institute partnered with the Society of American Foresters (SAF) to deliver a joint conference in Salt Lake City October 8-11, 2014. The conference was also co-located with the International Union of Forest Research Organizations (IUFRO) World Congress. With close to 4000 participants from more than 85 countries, this convergence of forest scientists, practitioners and managers proved to be one of the most prominent forestry events of the decade.

The conference was successful in highlighting Canadian forestry and research, expanding the Institute's international profile and in building new partnerships. The Institute received prominent and equal billing with both SAF and IUFRO. Many of our members and staff presented at various plenary and technical sessions. President Tat Smith addressed delegates in the opening plenary session and incoming President Al Stinson addressed the importance of global collaboration to some 2500 international delegates during the IUFRO closing ceremonies. Many members and guests attended our National Awards Banquet and hundreds visited the CIF/IFC display booth. A highlight of the conference, orchestrated by the CIF/IFC and the Duchy of Cornwall, was a video message from
His Royal Highness - The Prince of Wales, who addressed delegates during the opening plenary, speaking to the importance of international forestry knowledge exchange.

The Institute's business meetings and AGM also proved to be successful, with two important decisions resulting-the first relating to our Silver Ring policy and the second to a membership dues increase.

\section{Silver Rings}

During the past year the Institute conducted a review of the Silver Ring program through a national committee. The committee made many recommendations with one of the most important being the move to one ring design for all recognized programs. The rationale for this decision is that the Institute is an inclusive and interdisciplinary organization that does not have an accreditation or certification mandate. Our approach moving forward will be to recognize programs based on their ability to deliver on the 14 principles found in our code of ethics. Understanding that every recognized forestry or natural resources management institution (college or university) produces graduates with the talents, skills and training to benefit our multi-faceted, interdisciplinary sector, the Institute will now administer a single Silver Ring with a single design awarded to graduates from recognized schools, and to longtime members working in forestry. With an overwhelming majority of Board members voting in favour of this approach, a committee has been established to write new policies definitively describing the meaning, process and eligibility for receiving the CIF/IFC Silver Ring. These new policies will be implemented on September 1, 2015.

\section{Membership Dues Increase}

The Institute has not seen an increase in membership dues for five years. Two years ago, in an attempt to increase our membership, the Institute reduced baseline membership fees from $\$ 160$ to $\$ 100$. The anticipated increase in members, however, was not realized. A dues increase was therefore agreed upon. This increase more accurately reflects the value of membership benefits. Without this increase, the Institute would be unable to continue to deliver the wide array of products and services.

Beginning January 1, 2015 base membership dues* will be as follows:

Active: $\$ 140+$ tax
Hard Copy Chronicle: additional $\$ 60$

Retired: $\$ 60+$ tax

Hard Copy Chronicle: additional \$60

Student: $\$ 60+\operatorname{tax}$

Hard Copy Chronicle: additional $\$ 60$ 